\title{
CHEMICAL WEED CONTROL IN YOUNG CONIFER PLANTATIONS
}

\author{
D. S. PREest
}

\section{Forest Research Institute, N.Z. Forest Service, Rotorua \\ Summary}

Hand and mechanical methods have disadvantages and limitations which have led to aerial spraying with selective weedicides. Radiata pine (Pinus radiata) and Douglas fir (Pseudotsuga menziesii) show marked variations in tolerance to chemical treatments, depending on time of application and the chemical and formulation used. Radiata pine should be sprayed soon after planting, if possible before growth has resumed. Douglas fir is most sensitive during the growth flush. If spraying is delayed until the second or succeeding years, malformation of both species becomes progressively more severe.

The only weedicide in use for the selective control of woody weeds is 2,4,5-T emulsifiable ester in water. Recent Forest Research Institute experiments with a wide range of chemicals and formulations indicate that several are more selective and could be used on actively growing trees. A simazine-2,2-DPAamitrole mixture applied around the trees from the ground is used for grass control.

\section{INTRODUCTION}

THE AREA of exotic forest planted annually in New Zealand is approaching 30,000 acres. Over much of this, weed growth seriously competes with the young trees. Control measures, still predominantly hand methods, cost $£ 115,000$ to $£ 120,000$ annually.

Because of the disadvantages and limitations of hand and mechanical methods, selective weed control by chemicals applied by contract from the air has been widely tried, and in some instances accepted as a routine measure. It offers the possibility of an effective "one-shot" treatment at greatly reduced cost; little of the forest owner's labour is involved and little capital is tied up in equipment; very large areas can be covered in a short time; individual trees do not need to be located; and terrain is relatively unimportant. Disadvantages include dependence on the weather; in many instances the season of treatment is restricted; the time of maximum weed susceptibility is generally the time of least crop tolerance; trees not requiring release, especially the more vigorous, emergent ones, may be damaged or set back by the treatment; and the use of hormone-type weedicides is prohibited in certain areas because of the risk of damage to other crops.

The great bulk of chemical weed control in young plantations is carried out with fixed-wing aircraft or helicopters. A small amount, principally control of grass weeds, is done with knapsack sprayers, protectives cones being placed over the trees. Some grass spraying has been done with long hose lines from a wheeled tanker-pumper unit, but these are awkward to handle and vehicle access is often very limited or impossible in steep country. Backpack mist blowers have been used on a small scale, mainly for the control of indigenous hardwood regrowth competing with young trees planted in cut-over indigenous forest.

In all cases water is the preferred carrier. Oil carriers greatly reduce the selectivity of all the compounds tested. 


\section{CROP TOLERANCE}

Our knowledge of crop tolerance is restricted to radiata pine (Pinus radiata) and Douglas fir (Pseudotsuga menziesiî); it comes from screening and tolerance trials conducted at the Forest Resarch Institute and from large-scale aerial-spraying trials carried out independently by some conservancies. In the Institute work, various formulations and mixtures of a large range of chemicals have been tested, including 2,4-D, dichlorprop, 2,4-DB, 2,4,5-T, fenoprop, 2,4,5-TB, mixed isomers of 2,4,5-T, 2,3,6-TBA, dicamba, picloram paraquat, and 2,3,5-trichloro-4-pyridinol. Carriers have included water, diesel oil, and invert emulsions of water in diesel oil. Initial trials were mainly at $2 \mathrm{lb}, 4 \mathrm{lb}$, and $8 \mathrm{lb}$ of chemical in $100 \mathrm{gal}$ carrier, and later ones at $1 \mathrm{lb}, 2 \mathrm{lb}$, and $4 \mathrm{lb}$ in 50 gal carrier (all rates in active ingredient per acre). Paraquat and picloram were applied at $0.25 \mathrm{lb}, 0.5 \mathrm{lb}$, and $1 \mathrm{lb}$. Spraying was carried out from an overhead spray boom to simulate aerial application. Trees of normal planting size (one-year radiata pine and two- and three-year Douglas fir) were sprayed at various times during the first year after planting out. Between 20 and 30 trees were used for each treatment.

The following remarks are somewhat tentative, being based on general observations of these trials. More precise evaluation must await the processing of data on height increment and fresh weight. In a few instances attempts have been made to compare the cost of various treatments. It should be borne in mind, however, that such comparisons are very incomplete, as it has not yet been possible to study the effects of early spray damage on total yield.

\section{SeAsonal EfFects}

\section{Radiata Pine}

Except with the weedicides, such as paraquat and 2,3,5-trichloro4-pyridinol, which cause mainly contact injury, least damage occurs when spraying is done soon after planting, before the trees have resumed growth. Some contact injury and needle shedding occurs, but there is little or no distortion of the leader, and what does occur is soon corrected with the onset of new growth or, if persistent, is near enough to ground level not to affect future log quality. Once vigorous leader growth has recommenced after planting, the distortion and dieback (and the consequent stem malformation) caused by spraying become more and more pronounced the longer spraying is delayed. The influence of season is less noticeable in radiata pine than in Douglas fir, because in many parts of the country the former grows continuously almost the year round. If resting buds are formed, foliage damage and malformation are much reduced.

\section{Douglas Fir}

Tolerance varies markedly with season of application. Spraying with phenoxy compounds during the main growth flush (October to early January( can severely distort the leader and kill the new foliage. As with radiata pine, distortion becomes progressively worse if treatment is delayed until the second or succeeding years. Gross malformation occurs in the leaders of older trees, and log quality will undoubtedly be impaired. But once the new growth has hardened off, usually during the second half of January, a sudden marked improvement in tolerance to most compounds occurs. 


\section{Chemical Effects}

Tolerance to the chemicals and formulations used in the Institute trials varied enormously. In all cases the use of diesel oil as a carrier, whether alone or in invert emulsion, resulted in mortality or unacceptable damage to both species. Diesel oil alone at $100 \mathrm{gal}$ caused negligible injury. Heavy damage and mortality was caused to both species by 2,4-D ester, 4-CPA ester and amine, mixed isomers of 2,4,5-T ester, 2,3,6-TBA amine, dicamba amine, and paraquat, at rates likely to be effective against weeds such as gorse (Ulex europaeus), broom (Cytisus spp.), and bracken (Pterdium aquilinum var. esculentum). Damage included browning and death of foliage, needle shedding, death of buds, and dieback of the leader, and in the case of the phenoxy compounds, distortion of the upper needles, main stem, and branches where active growth was in progress. The benzoics caused failure of the terminal bud and those of the upper branches, with characteristic thickening or "clubbing" of the leader and branch tips. 2,3,6-TBA was less damaging than dicamba, but did not offer any advantages over 2,4,5-T ester. 2,3,5trichloro-4-pyridinol, which is claimed to be a grass killer, caused severe contact damage, stem dieback, and mortality in both species at $2 \mathrm{lb}, 4 \mathrm{lb}$ and $8 \mathrm{lb}$ when applied with a surfactant. Contact damage and temporary bleaching, without distortion, was caused by applications of $1 \mathrm{lb}$, but recovery appears to be good.

\section{Radiata Pine}

2,4,5-T ester appears to be too damaging at rates above $2 \mathrm{lb}$, but the amine causes very little damage at $4 \mathrm{lb}$ and may be acceptable for use on growing trees even at $8 \mathrm{lb}$. The various formulations of fenoprop are roughly similar in activity to the corresponding formulations of 2,4,5-T, and in view of their higher cost seem to offer no advantage. 2,4-D amine was more damaging than 2,4,5-T ester. Both the ester and the amine of diclorprop caused little damage at rates up to $4 \mathrm{lb}$, and the amine was acceptable at $8 \mathrm{lb}$. Similarly, the amine of 2,4,5-TB had almost no ill effect at $4 \mathrm{lb}$. Somewhat surprisingly, picloram produced negligible damage at 0.25 and $0.5 \mathrm{lb}$, and little at $1 \mathrm{lb}$, although at this rate depression of growth was evident. Damage from mixtures of picloram and 2,4,5-T amine at rates suitable for controlling gorse, lupin (Lupinus arboreus) and broom was very slight the main effect being to check terminal growth for a few weeks. In trials in Canterbury, radiata pine has been little affected by application of picloram to the soil at $2 \mathrm{lb}$ six months before planting.

\section{Douglas Fir}

When the foliage is soft, application of even $1 \mathrm{lb}$ or $2 \mathrm{lb}$ of 2,4,5-T ester may cause considerable distortion of new growth. Before growth has started, or when the new shoots have hardened off, however, applications of up to $4 \mathrm{lb}$ could be considered, the damage being limited to needle browning or shedding in the upper part of the tree. Good tolerance is shown to the amines of 2,4,5-T and $2,4,5-\mathrm{TB}$ at $4 \mathrm{lb}$, even at the height of the spring flush (midOctober). Roughly equal tolerance was shown to the various formulations of fenoprop used. The ester is less toxic than that of $2,4,5-\mathrm{T}$, and rates up to $4 \mathrm{lb}$ could probably be used on hardened foliage. The selectivity of this chemical for Douglas fir is favourably reported on overseas. 2,4-D amine and 2,4-DB ester caused 
little damage at rates up to $2 \mathrm{lb}$ and could possibly be used on soft little damage at rates up to $2 \mathrm{lb}$ and could possibly be used on sort acceptable at $2 \mathrm{lb}$ but not at $4 \mathrm{lb}$. Picloram is very persistent in Douglas fir. Autumn applications of $0.5 \mathrm{lb}$ and $1 \mathrm{lb}$ caused little damage at the time, but seriously affected new growth in the following spring, and traces of its activity could be discerned in new spring foliage again a year later. Damage consisted of the new spring foliage again a year later. Damage yellowing and dis, killing or inhibition of growth of existing buds, yning of the shoot tortion of new needles and by the benzoic acid derivatives. Applitips similar to $0.25,0.5$ and $1 \mathrm{lb}$ with a surfactant caused severe damage, cations of 0.25 , 0.5 and the damage was much less serious, and is but without surfactant the damagession of growth was evident at $11 \mathrm{l}$ ratc. Up to $0.5 \mathrm{lb}$ picloram mixed with $1 \mathrm{lb} 2,4,5-\mathrm{T}$ ester or 245-T amine caused little permanent damage when no surfactant 2,4,5-T amine coures of picloram and 2,4-D amine without surfactant was used. Mixtures of picloram and 2,4-D amine without surfactant were $0.5 \mathrm{lb}$ picloram and $2 \mathrm{lb}$ 2,4-D amine. Paraquat could possibly be used on hardened foliage at rates up to $0.25 \mathrm{lb}$ with surfactant and up to $1 \mathrm{lb}$ without.

\section{TREATMENTS FOR SPECIFIC WEEDS}

BRACKEN FERN (Pteridium aquilinum var. esculentum)

At present there are no chemicals suitable for the selective control of bracken fern in radiata pine or Douglas fir plantations. Chemicals such as 4-CPA and picloram are too expensive and/or too damaging at rates likely to be effective against bracken fern. Moreover, the time of application is reputedly very restricted and Mory critical for success with these chemicals, and it would be difficult to treat large areas in the time available.

\section{SoFt Broom (Cytisus monspessulanus)}

Experience with aerial release spraying is limited. Good kills, with no further release needed, have been obtained by the Forest Service near Rotorua with 1.2 to $3.6 \mathrm{lb}$ of $2,4,5-\mathrm{T}$ emulsifiable ester in 40 to 80 gal water per acre applied by fixed-wing plane and in 40 thmaster. Costs varied from $£ 310$ s. to $£ 610$ s. per acre. Some damage was done by November spraying to three-year-old radiata damage was done by November spraying to pine on flight-path overlaps and on rige tops, but the $2,4,5-\mathrm{T}$ emulregarded as satisfactory. An Aprer acre appears to be achieving a good kill of broom and to be leaving Douglas fir, planted the previous winter, almost totally unaffected.

Of several treatments applied by overhead boom in a recent (late January, 1966) Forest Research Institute simulated aerial(late January, 1966) Rotorua, 2,4,5-T emulsifiable ester at $2 \mathrm{lb}$ and spraying trial near Rotorua, 2,4,5-T and $0.33 \mathrm{lb}$ 2,4,5-T amine applied a mixture containing $2 \mathrm{oz}$ picloram and $0.33 \mathrm{lb}$ 2,4,5-T amine applied in water at 25 gal per acre gave complete or near-complete kills of very dense two-year-old broom (4ther species at any season would be acceptable for releasing either species at any season, 2,4,5-T ester were used during the spring flush.

\section{GoRSE (Ulex europaeus)}

Not only is gorse a problem in the establishment of young plantations, but it can also present a formidable deterrent to those 
engaged in early pruning and thinning operations. Trial work in Southland and Canterbury conservancies is now being carried out on more thorough land-preparation methods involving, in the one instance, various spraying and burning regimes, and, in the other, intensive cultivation and ripping, in an effort to gain long-term control of gorse. In the meantime, competition from seedlings and regrowth is being countered by aerial spraying in most forests where gorse is troublesome.

The usual practice is to burn in autumn, plant in winter, and spray the seedling and regrowth gorse in spring or early summer with 2,45-T emulsifiable ester at $0.9 \mathrm{lb}$ in 25 gal of water per acre. Some good results have been obtained in Nelson with volumes down to 12.5 gal per acre. In a Forest Research Institute trial near Rotorua 2, 2.5-T ester was applied in late January at $0.5,1,2$, and $4 \mathrm{lb}$, each in water at rates of $6.25,12.5,25$, and 50 gal, to stunted two-year-old seedling gorse. Of these treatments, $1 \mathrm{lb}$ in $12.5 \mathrm{gal}$ appears to be the cheapest, giving satisfactory control for release purposes. This has not been tested on regrowth gorse. Recent costs purposes. Service applications at 25 gal, including cost of chemical, have been about $£ 2$ per acre for fixed-wing plane and $£ 3$ per acre for helicopter.

So far the gorse-tested alternatives to 2,4,5-T emulsifiable ester are few. Mixtures of 0.25 or $0.5 \mathrm{lb}$ of picloram and $1 \mathrm{lb}$ of $2,4,5-\mathrm{T}$ amine achieved control comparable with that of 2,4,5-T ester at $4 \mathrm{lb}$ in simulated aerial-application trials conducted by the Institute near Rotorua and in Southland. The greater tolerance of radiata near Rotorua and in Southland. The greater tolerance of race in releasing this species, though cost is a disadvantage. The use of picloram at these rates on Douglas fir should be restricted to times when the Douglas fir foliage is mature, but 2,4,5-T emulsifiable ester is just as selective at these times, and is much cheaper.

\section{GRASS WEEDS}

Grass weeds are a problem mainly where low-production or unstable farm land is being reforested. The most troublesome are Yorkshire fog (Holcus lanatus), tall fescue (Festuca arundinacea), cocksfoot (Dactylis glomerata), browntop (Agrostis tenuis), nassella tussock (Nasella trichotoma), and ryegrass (Lolium spp.). The clovers (Trifolium spp.) and Lotus major can be a problem on a limited scale.

Suitable selective weedicides for grass control are unknown although paraquat at $0.25 \mathrm{lb}$ with a surfactant could be used on Douglas fir just before the spring flush to give short-term control Chemical treatments usually involve shielding the tree with a metal cone and spraying the grass immediately around it. A mixture of simazine $(40 \% \mathrm{w} / \mathrm{w}), 2,2-\mathrm{DPA} \quad(25.75 \% \mathrm{w} / \mathrm{w})$, and amitrole of simazine $(40 \% \mathrm{w} / \mathrm{w}), 2,2-\mathrm{DPA}(25.75 \% \mathrm{w} / \mathrm{w})$, and amitrole If a knapsack sprayer is used, it takes 4-8 gal (i.e., 0.5 to $1.0 \mathrm{lb}$ of chemical) to spray a ring 9 to $12 \mathrm{in}$. wide around each tree. Costs vary from $£ 310 \mathrm{~s}$. to $£ 713 \mathrm{~s}$. per acre. Application should be made in early spring while the grass is short (6 in. or less). Once it becomes tall and rank, the degree of control achieved is greatly reconed and the chemicals can be shed on to the trees, where the 2,2-DPA and amitrole components cause considerable damage and, in many cases, death. Attempts have been made to spray strips or spots before planting, but so far the difficulty of achieving proper spacing from the previous but invisible line of spraying has prevented the adoption of this technique. The use of a red marker dye has proved ineffective. 
In one instance spraying with paraquat (rates not known) has resulted in the replacement of the grasses by an acceptable ring of low white clover. Where clovers are a problem they could easily be controlled by an overall spray of picloram at 1 or $2 \mathrm{oz}$. The limited tolerance shown towards 2,3,5-trichloro-4-pyridinol suggests that this chemical may be useful against grass if control can be achieved at rates of $1 \mathrm{lb}$ or less.

\section{INDIGENOUS SCRUB HARDWOODS}

The common indigenous hardwood weeds vary tremendously in their reactions to weedicides, from those such as wineberry (Aristotelia serrata) and Coprosma australis, which are very sensitive to 2,4,5-T emulsifiable ester in water, to species such as mahoe (Melicytus ramiflorus) and kamahi (Weinmannia racemosa), which are very resistant to it. Of the chemicals suitable for conifer release few have been tested on indigenous species, and there does not appear to be any as yet superior to 2,4,5-T emulsifiable ester in water. Species controlled well, or moderately well by this formulation include wineberry, Coprosma australis, C. lucida, C. robusta, Melicytus lanceolatus (seedlings), pate (Schefflera digitata), and bush lawyer (Rubus australis). Fuchsia excorticata and Neopanax arboreum tend to resprout after initial defoliation.

A knapsack mist blower has been successfully used in the autumn near Rotorua to apply $1.0 \%$ and $0.5 \%$ 2,4,5-T emulsifiable ester in water to release Douglas fir, Japanese cedar (Cryptomeria japonica), western red cedar (Thuja plicata), rimu (Dacrydium cupressinum) totara (Podocarpus totara), and kahikatea (Podocarpus dacrydioides) from seedling and coppice regrowth of the above species arising after tractor clearing of logged indigenous forest. Damage to these conifers was negligible, but Cupressus lusitanica and C. macrocarpa were seriously damaged.

\section{SYCAMORE (Acer pseudoplatanus)}

Seedling and coppice sycamore have become weeds in a few forests. Suppressed seedlings, only a few inches high, are capable of growing 3 to $6 \mathrm{ft}$ in the first year after removal of the inhibiting overwood, and coppice 5 to $10 \mathrm{ft}$ high can develop in one year from cut stumps, exposed damaged roots, and tractor-crushed stems.

The results achieved by applying 2,4,5-T and 2,4-D esters in water and diesel oil to coppice and to mature trees by mist blower and from aircraft have been disappointing. Defoliation and slight stem dieback have occurred with rates of 1.8 and $3.6 \mathrm{Ib}$.

Control of seedlings looks more promising. In Institute trials near Tapanui in January with a large number of different chemicals and formulations applied as simulated aerial sprays in $50 \mathrm{gal}$ water, the following treatments gave complete or near-complete kills :

(1) $0.5 \mathrm{lb}$ picloram potassium salt with surfactant

(2) $0.25 \mathrm{lb}$ picloram potassium salt plus $1 \mathrm{lb}$ 2,4,5-T amine with surfactant

(3) $0.5 \mathrm{lb}$ picloram potassium salt plus $1 \mathrm{lb}$ 2,4,5-T amine without surfactant.

A small mist blower trial in the same area, in which $7.2 \mathrm{lb} 2,4,5-\mathrm{T}$ oil-miscible ester in 50 gal diesel oil (rate per acre unknown) was 
applied to leafless seedlings in July, has also achieved a good kill, but this treatment would be far too damaging for release work.

\section{LUPIN (Lupinus arboreus)}

Aerial spraying for selective control of seedling and semi-mature yellow tree lupin has been carried out by the Forest Service since 1962 at Santoft on the Manawatu coast, and at Woodhill near Auckland; and more recently in the central North Island. At first, spraying was done by fixed-wing plane with a mixture of 2,4-D and $2,4,5-\mathrm{T}$ emulsifiable esters at $1.8 \mathrm{lb}$ and $0.9 \mathrm{lb}$, respectively, in $30 \mathrm{ga}$ water. Since then there has been a swing towards use of the less damaging 2,4,5-T ester alone, and towards a steady reduction both in rate of chemical and in volume per acre. Today good results are being achieved with as little as $0.34 \mathrm{lb} 2,4,5-\mathrm{T}$ ester in 15 gal water (total cost $£ 16 \mathrm{~s} .6 \mathrm{~d}$.) and, in one instance, $0.45 \mathrm{lb} 2,4-\mathrm{D}$ ester in $10 \mathrm{gal}$ water, both applied by helicopter. The preferred season for spraying lupin-infested radiata pine plantations would appear to be OctoberDecember, although treatments later in the summer have been quite successful.

In simulated aerial-application trials conducted by the Forest Research Institute, the following treatments gave complete, or almost complete, control of mature lupin in early February, $0.25 \%$ surfactant being added to each formulation:

(1) $1 \mathrm{lb} 2,4,5$-ester in 6.25 gal water

(2) $0.5 \mathrm{lb} 2,4,5-\mathrm{T}$ ester in 25 gal water

(3) $0.5 \mathrm{lb} 2,4,5-\mathrm{T}$ amine in 25 gal water

(4) $0.5 \mathrm{lb} 2,4-\mathrm{D}$ ester in $25 \mathrm{gal}$ water

(5) $2 \mathrm{oz}$ picloram in 25 gal water

(6) $1 \mathrm{oz}$ picloram plus $0.5 \mathrm{lb} 2,4,5-\mathrm{T}$ amine in 25 gal water

It is probable that the volume could have been reduced in treatments (2) to (6) to something like 10 gal, or even less. For radiata pine and Douglas fir the safest and most economical treatment would be 0.5 to $1 \mathrm{lb} 2,4,5-\mathrm{T}$ amine in 10 gal applied with a surfactant. Damage to both tree species would be entirely negligible, even at the height of the growing season. Unfortunately, this formulation is not available commercially. A safe but much more expensive alternative would be the commercially available picloram-2,4,5-T amine mixture applied at a rate containing 1 to $2 \mathrm{oz}$ picloram per acre. 2,4-D amine, which is available, would be safe and very econominal at $1.0 \mathrm{lb}$, but it has not yet been tested on lupin.

At present the main cost in lupin control is flying, and the biggest economies can be obtained by reducing the volumes applied. Interest is now being taken in the use of rotary atomizers to see if this very susceptible species can be controlled at extremely low volumes.

\section{ACKNOWLEDGEMENTS}

I am very grateful to the various Conservators of Forests for supplying information on their current spraying practice, and to Ivon Watkins-Dow Ltd. for their helpful advice and the free supply of many of the chemicals used in the Institute's spraying trials. 